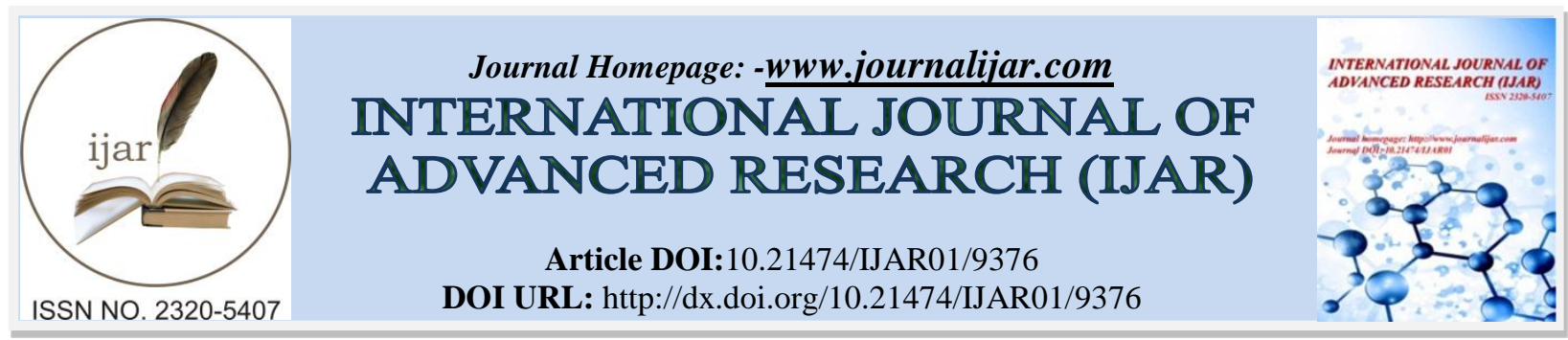

RESEARCH ARTICLE

\title{
QUALITY INFLUENCES OF WORK LIFE AND WORK MOTIVATION TO ORGANISATION PERFORMANCE OF PT. SEMEN TO NASA.
}

\author{
Muhammad Kafrawi Yunus ${ }^{1}$, Haris Maupa ${ }^{2}$, Abdul Rachman Laba ${ }^{2}$ and Muhammad Idrus Taba ${ }^{2}$. \\ 1. Department of Management, Faculty of Economics, Bosowa University. \\ 2. Faculty of Economics and Business, Hasanuddin University.
}

\section{Manuscript Info}

Manuscript History

Received: 10 May 2019

Final Accepted: 12 June 2019

Published: July 2019

Key words:-

Quality of Work Life, Work Motivation,

Organizational Performance.

\begin{abstract}
The company staff have not shown the optimal performance because of the staff's main facilities and supported facilties have not given yet by the company so, the staff are lack of work motivation. The good working facilities and environment related to the employees' satisfaction of their works. The research aim at evaluating the amount of the quality of work life and work motivation to the organisation performance, and how the influences of work motivation in moderating the relationship of quality of work life to organisation performance at the cement company, PT. Semen Tonasa in South Sulawesi. The type of data used in the study is the questionnaire primary data. The sample of the study was 48 respondents. The data were analyzed by using SmartPLS version 3.0 software. The primary questionnaires data which collected from the staff of the cement company of PT. Sement Tonasa in South Sulawesi. The results of the study reveal that quality of work life and work motivation influence the organisational performance of PT. Semen Tonasa, but work motivation does not moderate to strengthen the relationship of the quality of work life to organisational performance.
\end{abstract}

Copy Right, IJAR, 2019,. All rights reserved.

\section{Introduction:-}

Globalisation age needs the high effectiveness and efficiences of organisation to still survive in the compatition among the organisations. So, it needs the good and strong industry, and has compatitive power in the national and international market (Gobel, 2010). To keep the market position, the company needs to improve the new inovation in product atributes (quality, prices, and promotion) in the each brands wich have been mapped in the consumen perception mapping (Maikah, 2015). Such the cemen companies in Indonesia. The marketing performance in Indonesia has good performance, this proved by the cement higher selling both in national and international export than the years before (Assosiasi Semen Indonesia, 2018). The company strategy target become the top position cement production company to improve the communities satisfaction through internal and external condition to create the business study, the best standard services by the human resources who have education, skill, and business ethics. Supporting the BUMN minestry regulation, the Company has some cooparation strategies and business strategies to get their targets.

Corresponding Author: -Muhammad Kafrawi Yunus.

Address: - Department of Management, Faculty of Economics, Bosowa University. 
The company become a business based on the knowledge which is hopped to give Value Added to the company. So, the company gets profit that will have positive impact to the company performance. The company cannot only focused to the production quantity to compate in the market but also need Value Added which can be offered to the customers to get good compatition (Roos et al, 2005). So, a company has to apply and develope intelectual capital in the organisation, (Ulum, 2009: 20-30), "Intellectual Capital as knowledge sources in the form of employees, customers, proceesing or technology that company uses in processing of company value. One of the example, today, the employee who needed without see the quantity but the employee quality itself. By the quality of the employees will give good idea and innovation which can improve the value and capability of campany to compate with others.

The improvement of the cement marketing performance in Indonesia is influenced by the cement production performence which supported by the human sources performance (Iyigun, et al, 2012). The evaluation to each organisation performance is important thing because it can be used as a measurement of successful organisation for certain time. The evaluation can be used as the input for improvement and correction the organisation performance. Bastian (2001:329) states that the organisation performance is as the image of the organisation achievement level to attain the targets, goal, visi, and mission. So, the organisation has to understand the factors that influence a organisation performance.

As in the PT. Semen Tonasa company, to keep the high demand to the cement for the next ten years in order to improve the performance. The diagram of profit condition at PT. Semen Tonasa company period 2013-2017 in the Chart 1.

Chart 1:-The diagram of profit condition at PT. Semen Tonasa company period 2013-2017

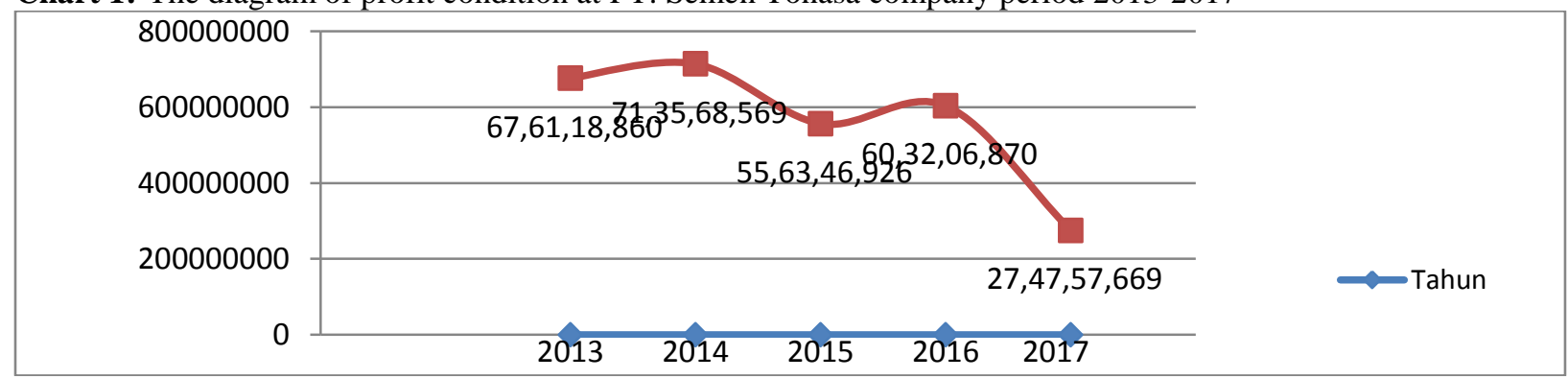

\section{Source: PT. Semen Tonasa, 2019}

The chart above shows the PT. Semen Tonasa profit condition in period 2013-2017 which has fluctuation. The highest profit in 2014 is Rp 713.568.569. This situation decrease in 2017 to Rp 274.757.669, so, the PT. Semen Tonasa company always improve the selling and reduce the cost to increase the company profit. The company always make inovation to improve the employees' performance to get company performance improvement.

From the business side, the Firm efforts to improve the performance for the long term target to support the segment market and market expansion also to establish cement bagging unit. Supporting by 1.282 staff of PT. Semen Tonasa with high working productivity is hopped can support the operational company to defend the products stock in the domestic market and to meet an international demand. Optimasing all the business profit sources and organising also improving the professional and productive human resources to improve the company performance.

In improving the organisation performance, quality of work life is the main problem which needs organisation attention (Lewis, et al, 2001). The creativity of good quality of work life makes working satisfaction because the willingness, need, and staff value can be attained in the organisation. The successful creation of quality of work life in a company gives effect to the specific things to the staff such as working satisfaction, motivation, the staff participation. Thereby, the quality of work life is the good way to improve the human resource quality in company. By the processing, human resources will be more responsible to their works (Zin, 2004).

Besides, quality of work life, the work motivation factor also has important role to improve the organisation performance. Gibson et al. (1996) state that motivation as the concept that used to describe the individual motivation which motivate and guide the doer. According to Maslow (1994) that staff's work motivation will effect to 
performance that pop out from the staff themself (internal motivation) or motivation from out side the staff (external motivation).

The company employees have not shown the optimal performance because of the employees' main facilities and supported facilties have not given yet by the company make the employees are lack of work motivation. Good facilities and work environment relate to the staff bond as the manifestation of satisfaction to the work has been done. The staff feel that they do not get fair enough direct finacial compensation as their hope. So, the staff use the indirect compensation, such as safety, work security, and pospone the work hopefully to get overtime. This situation will get extra income related to the organisation justice.

Based on the background above, the objective of the research is to analyze and evaluate how the effect of quality of work life and work motivation to the organisation performance and how the effect of work motivation in moderating relates to the quality of work life to the organisation performance at PT. Semen Tonasa, as the cement company in South Sulawesi.

\section{Literature Review}

\section{Quality of Work Life}

Robbins (2007) defined quality of work life as a process of how an organization respons the employee needs with the result is the employees have the chance to make a plan of their own life in their work environment. According to Flippo (2005) Quality of work life is every single improvement activity in every level of an organization to effectify the organization through its prestige improvement and the human development.

Parvar et al., (2013) defined Quality of Work Life as an effective program to improve the work condition and the organization effectiveness. According to Parvar, the quality of work life play as employee controller which related to the quality of work and quality of work life of the employee and also help the supervisors to make any improvement in the organization.

Tongo (2015) defined QWL as the satisfaction of the employee on several kinds of needs through resources, activity, and the result of their part in the company. Kanten (2012) said that there are Eight of Quality of Work Life dementions. They are:

1. Adequate and fair compensation, salary the employee gain from the company can fulfil the common standard salary and fulfil their daily need.

2. Safe and healthy environment, safe and healthy environment which related to the employees work environment, the comfort situation for the physic and their health.

3. Development of human capacity. The employee quality of work life will be better when the company give the autonomy the employees to use their skill and competence to finish their work.

4. Growth and security, an important factor which keeps the quality of work life and classified as work secure, personal improvement and career advance.

5. Social integration, refers to an important which related to how the employees have the feeling as if the company is their own, so they will feel free, opened, trust in the relationship.

6. Constitutionalism refers to the employee rights and how the rights secure them.

7. Total life space, the balance of work time and brake time since the employee also has other role outside of their job.

8. Social relevance refers to the responsibility of the company to keep the quality and condition of work.

Based on the defenitions above it can be concluded that the quality of work life demention include the enough and fair salary; healthy work environment, secure and safe; there is an opportunuity to grow and develop; the opportunity to use and to develop the competence; the balance between work, personal life, family life; good work relationship; and the social responsibility which improve the employee proud.

\section{Work Motivation}

Spector (2000) defined motivation as a series of process which shows, guides, and keeps the human behavior to get their purpose. Motivation exists because of the need of the human which need to be fulfilled. When the material and non material compensation gained is satisfied, the work spirit will improve (Cherington, 1995). Ahmed et., al, (2010:70) in his research result found out that motivation factor is the main part and plays an impotant role in 
improving the employee satisfaction. The employee whose need fulfilled as their work reward can improve organization performance.

It could be said that moltivation as a booster for the employees to do or to reach their purpose. Motivation is also said as a plan or desire to grasp the success and to avoid the failure. Moltivation is a process to gain the goal. A person who has the motivation means the power to success as said by Mangkunegara (2007) that motive defined as self pushed to activate ended by self adoption, and the self adoption will satisfied the motive. While based on Mangkunegara (2007) point of view which becomes the reference to define the motive defined that motive is the need stimulated which oriented to the individual purpose satisfaction.

It can be concluded that work motivation is a condition activate the human and cause spirit or stimulus to do an activity which is shown in an effort to gain the goal; strong or weak the motivation will influence the prestige gain.

\section{Organiztion Performance}

Performance refers to the level of company achievement or the company performance in a certain period. The company performance is an important factor in developing the company. The goal of the company is to stay exist, gain the profit, and stay growth can be reached when the the company has good performance. The company performance shown by the level of selling, level of profit, level return of capital, the level of turn-over and the market segment (Jauch and Glueck, 1998).

The organization performance or the company performance is the indicator of the performance level gain and show the success of the manager/the employer. Performance is the result gain from the behavior of the organization members (Gibson, 1998). Aragon-sanchez and Sanchez-Marin, (2005) used 3 indicators to measure the business performance, they are; efficiency, growth, and profit. The company performance is a multy aspects fenomena which is very difficult to measure.

Schwartz (1999) view the management perfomance as a style of management which based on the open communication between the manager and the staff about the goal decision, give the feedback from the manager to the staff or from the staff to the manager. Costello (1994:3) stated that management performance is the base and the power stimulating all the organization decision, work effort, and the resource allocation. Many organizations get difficult in growing and applying effective performance management. The key success of the effective system is performance. An organization will stay exist when it has good performance and high level performance.

\section{Previous Findings}

Previous findings related to this research as follows:

1. Alfani (2018) concluded that Quality of Work Life influential toward staff performance when the staff has high Quality of Work Life will improve their performance.

2. Tanaya and Chandan (2015) shown that better QWL is the success to attract and to keep the motivated and have good quality staff which may improve the quality of the company service.

3. Shiney (2012), from his research is found out that QWL has significant relationship with the organization performance. The variable QWL are the company health and safe policy, free lunch for the staff, transportation for the staff, coaching, leave day, family life, and healthy life.

4. Matthew Abioro (2013) shown that the staff work motivation has positive influence toward the organization performance. So, it is recommended that an organization must seriously pay attention to the staff motivation to facilitate work delivery and the effective performance.

5. Ovidiu (2013) shown that motivation and performance of the staff are the important means of any organization long term success, there is positive relationship between staff motivation and the organization effectiveness.

6. Michael (2016), the empirical proof show that motivated staff will make organization performance better.

7. Ifrah et al (2017) showed significant relationship between motivations means such as salary the staff receieved and their performance. The research finding shows that 32\% staff motivation toward the organization performance.

\section{Framework}

Organization and staff are two elements in mutual demand which can not be separated each other. Commonly, Staff has potential to be given to the organization, so the human resource is the one of the important product factors for the organization to gain its goal. Every organization always tries to get skillful human resource. Organization always 
tries to improve the staff performance though the organization still pays attention to the other factors. Just like as the quality of work life and the work motivation become the booster in the process of gaining the goal of the organization.

The relationship between the influence of quality of work life and the work motivation toward the organization performance of PT. Semen Tonasa in this research can be shown in the following theory framework in Picture 2:

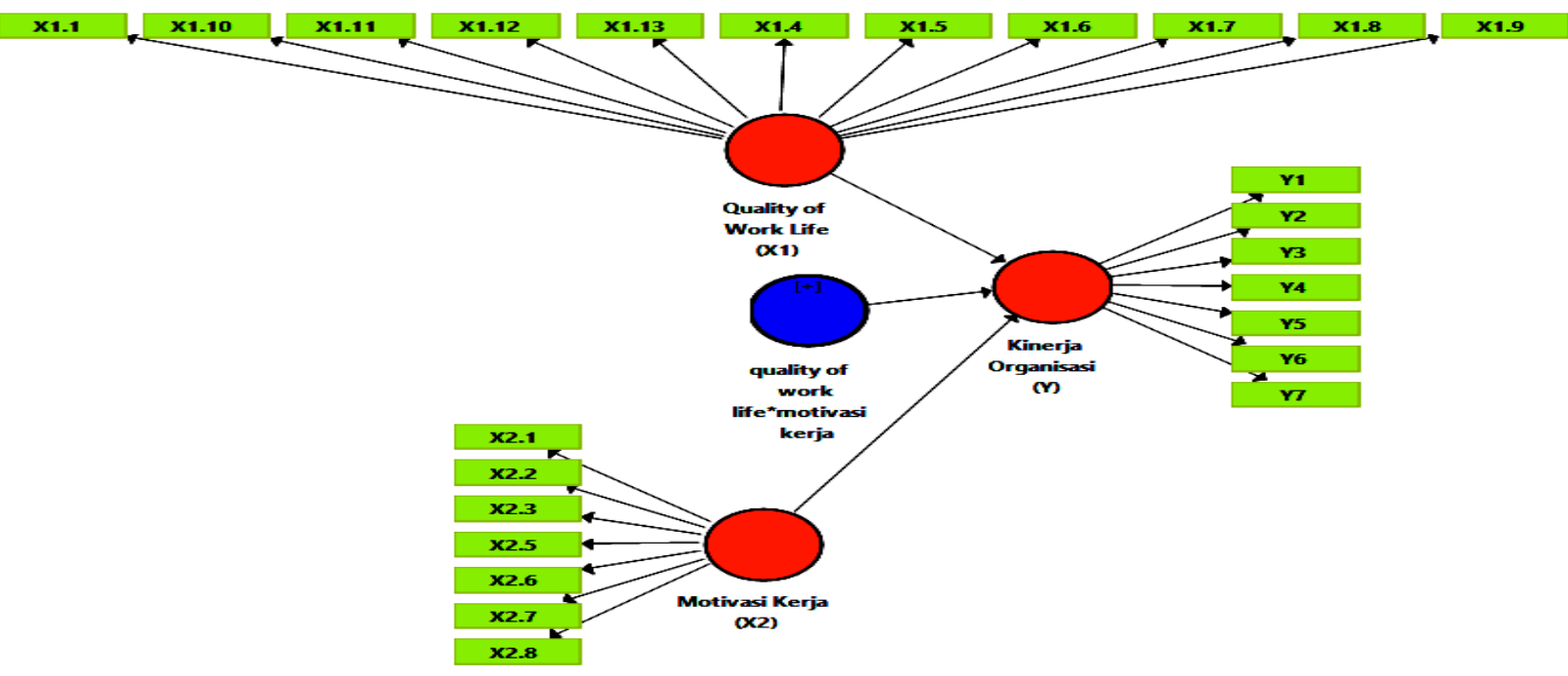

Picture2:-Research Framework

\section{Research Hypotheses}

Based on the problem statement and the objective of the research and strengthen by review of literature and empiris study, the hypotheses arranged as follows:

1. Hypotheses-1: the quality of work life and work motivation is positively influence and significantly influences the organization performance of PT. Semen Tonasa in South Sulawesi.

2. Hypotheses-2: The work motivation moderates the influence of the quality of work life toward the organization performance of PT. Semen Tonasa in South Sulawesi.

\section{Research Methodology: -}

Research Location

To gain the data needed in this research, the researcher studied at PT. Semen Tonasa which located in Pangkep Regency, South Sulawesi. The time allotment is about 3 months.

\section{Sample}

The total population is 1.282, so the researcher used total sampling using Slovin (Umar, 2008: 78) model that is purposive sampling technique, directly point the respondent who has the research criteria. Total sample was 97 respondents.

\section{Data Analysis Method}

This research use SmartPLS Software versi 2 data analysis method, using computer. According to Jogiyanto and Abdillah (2009) PLS (Partial Least Square) is: Structural Equivalent Method (SEM) based on simultantly variant can test both measurement model and structural model. Measurement model used to test the validity and realibility, structural model used to test causality (hyphotheses test and prediction model). Then Jogiyanto and Abdillah (2009) stated that Partial Least Squares (PLS) is multivariant statistic technique which compares the dependent variable and the independent variable. 


\section{Findings And Discussion:- \\ Research Findings \\ Description of Research Data Quality Evaluation \\ Evaluation Measurement (Outer) Model \\ Convergent Validity}

The research done to validity and reliability test on each variables. The variables are quality of work life and work motivation to the PT. Semen Tonasa company by using software SmartPLS. The individual reflexiveis valid if has loading's score with the latent variable that is ,measured is $\geq 0.5$, if one indicator has loading score $<0.5$ so, the indicator has to be droped because will be indicated that indicator is not enough to measure the latent variables precisely. Based on the first evaluation on the picture 1. This research model shows variables X1.2, X1.3, and X2.4 with the factor loading score faktor under 0,5 which is not required so, have to be dispelled out from the research model and then do the second test.

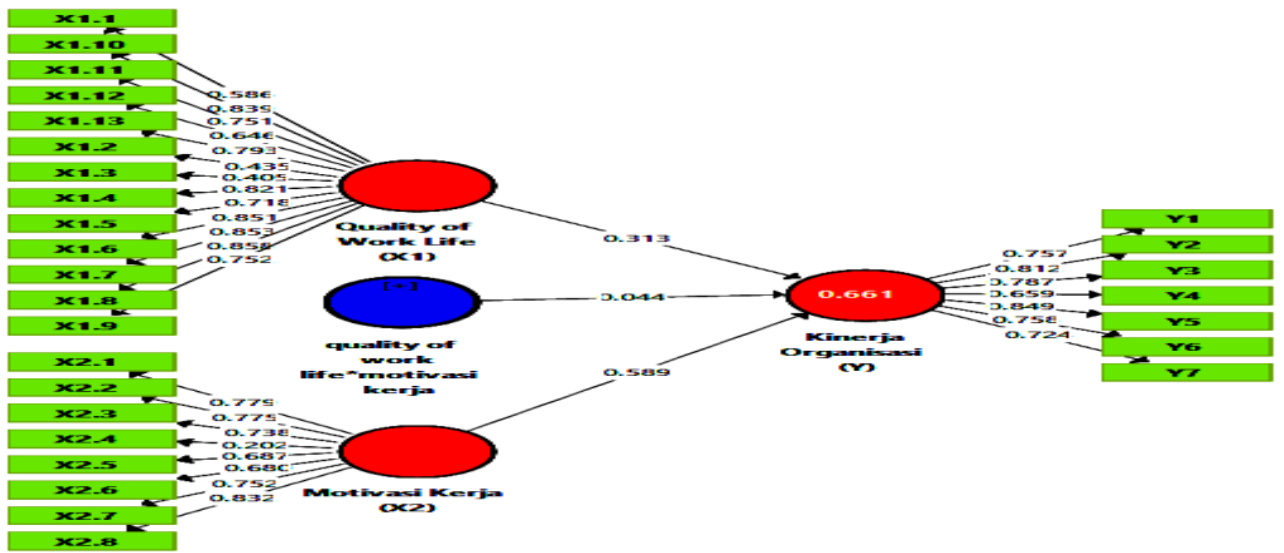

Picture 3:-The First Evaluation Model Outer Loadings

Based on the processing result by using SmartPLS some indicator outer has been up to standard. While on the picture 4 , shows the outer score model or corelation between construct and variable which suitable to the convergen validity because speading of score loading factor which has score 0.50 loading factor and it has been valid.

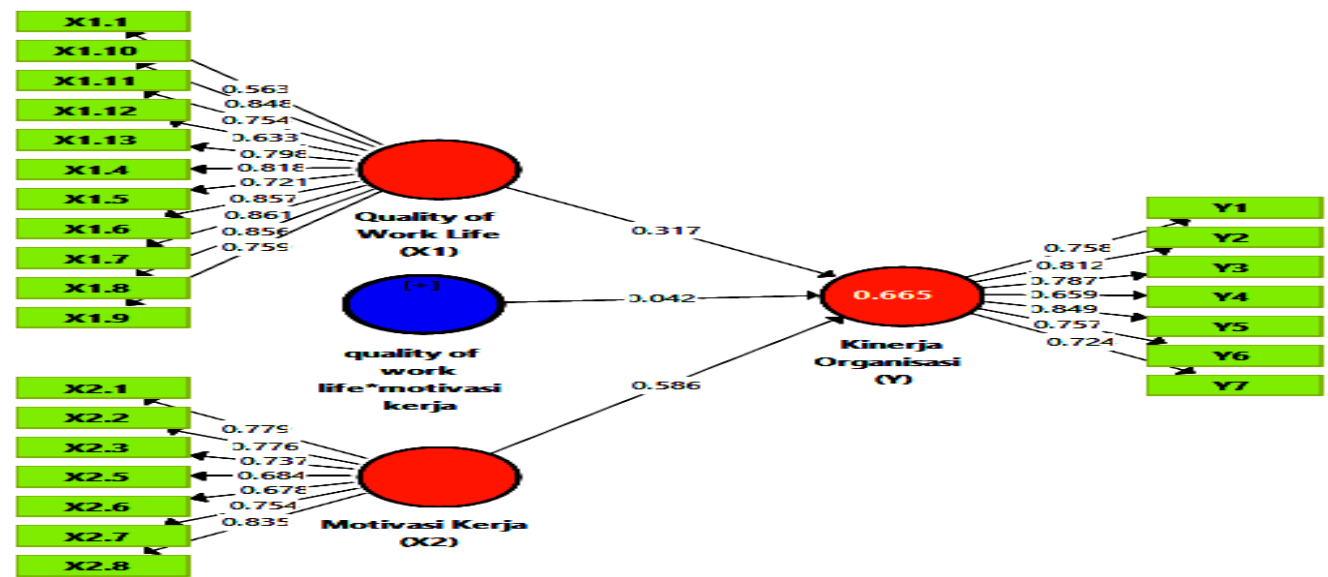

Picture 4:-The Second Test Model Outer Loadings

The processing by using SmartPLS can be seen on picture 4. The outer model score or corelation between construct and variable in the previous which has been met to the convergen validity, because this research model shows indicator outer which has been required, and the loading factor indicator is still above the loading standard with the latent variable which has been measured $\geq 0.5$. 


\section{Discriminate Validity}

Discriminant validity is done to ensure that every concept of each latent variable is different from the other variables. The model has good discriminant validity if the loading score of each indicator of a latent variable has highest loading score than the other loading score to the other latent variable. Discriminant validity test is done to prove whether the indicator in the construct will has biggest loading factor to the construct that made from the loading factor withthe other construct. The cross loading can be seen on the tabel 1 as follows:

Table 1:-Cross Loading

\begin{tabular}{|c|c|c|c|}
\hline & Organisation Performance_(Y) & Work Motivation_(X2) & Quality of Work Life_(X1) \\
\hline X1.1 & 0.336 & 0.341 & 0.563 \\
\hline X1.10 & 0.615 & 0.587 & 0.848 \\
\hline X1.11 & 0.572 & 0.576 & 0.754 \\
\hline X1.12 & 0.374 & 0.425 & 0.633 \\
\hline X1.13 & 0.597 & 0.61 & 0.798 \\
\hline X1.5 & 0.482 & 0.542 & 0.818 \\
\hline X1.6 & 0.493 & 0.449 & 0.721 \\
\hline X1.7 & 0.523 & 0.546 & 0.857 \\
\hline X1.8 & 0.594 & 0.515 & 0.861 \\
\hline X1.9 & 0.627 & 0.603 & 0.856 \\
\hline X2.1 & 0.488 & 0.42 & 0.759 \\
\hline X2.2 & 0.595 & 0.779 & 0.656 \\
\hline X2.3 & 0.589 & 0.776 & 0.625 \\
\hline X2.5 & 0.511 & 0.737 & 0.485 \\
\hline X2.6 & 0.524 & 0.684 & 0.348 \\
\hline X2.7 & 0.491 & 0.678 & 0.312 \\
\hline X2.8 & 0.691 & 0.754 & 0.435 \\
\hline Y1 & 0.682 & 0.835 & 0.605 \\
\hline Y2 & 0.758 & 0.61 & 0.575 \\
\hline Y3 & 0.812 & 0.633 & 0.613 \\
\hline Y4 & 0.787 & 0.542 & 0.561 \\
\hline Y5 & 0.659 & 0.52 & 0.442 \\
\hline Y6 & 0.849 & 0.76 & 0.548 \\
\hline Y7 & 0.757 & 0.573 & \\
\hline Source: Tabulation Data SmartPLS, 2019. & 0.537 & 0.418 \\
\hline
\end{tabular}

Based on the table 1, there is good discriminate validity so, indicator corelation score to its construct is higher than indicator corelation score with other construct. The table also shows that indicators of other latent variables also has higher loading factor score than other loading factor.

\section{Composite Reliability and Cronbach's Alpha}

Besides, the construct test, the reabilty construct also which measure by composite reliability dan cronbach's alpha from the indicator block that measured the construct. The composite reliability test result of Smart PLS as follows:

Table 2:-Composite Reliability and Cronbach's Alpha

\begin{tabular}{|l|c|}
\hline & Composite Reliability \\
\hline Organisation Performance_(Y) & 0.908 \\
\hline Work Motivation_(X2) & 0.900 \\
\hline Quality of Work Life_(X1) & 0.942 \\
\hline Source: Tabulation Data through PLS, 2019 & \\
\hline
\end{tabular}

The construct is reliable if has composite reliability score above is 0,70 . Output result of SmartPLS all of constructs above have composite reliability score above is 0,70 . So, can be concluded that the construct has good reliability. 


\section{Structural Model Test (Inner Model)}

The significance test model using boostraping technique, the result can be seen on the table 3 below. The picture model shows $\mathrm{t}$ score statistic with relation between variables will be compared with $\mathrm{t}$ table score.

Table 3:-Path Coefficient

\begin{tabular}{|c|c|c|c|c|c|}
\hline & $\begin{array}{c}\text { Original } \\
\text { Sample }(\mathrm{O})\end{array}$ & $\begin{array}{c}\text { Sample } \\
\text { Rate } \\
\text { (M) }\end{array}$ & $\begin{array}{l}\text { Deviasion Standard } \\
\quad \text { (STDEV) }\end{array}$ & $\begin{array}{c}\mathrm{T} \\
\text { Statistic } \\
(\mid \\
\text { O/STDE } \\
\mathrm{V} \mid) \\
\end{array}$ & $\begin{array}{c}\mathrm{P} \\
\text { Val } \\
\text { ues }\end{array}$ \\
\hline $\begin{array}{l}\text { Quality of Work Life_(X1) -> Organisation } \\
\text { Performance_(Y) }\end{array}$ & 0.317 & 0.317 & 0.095 & 3.333 & $\begin{array}{r}0.00 \\
1\end{array}$ \\
\hline $\begin{array}{l}\text { Work Motivation_(X2) -> Organisastion } \\
\text { Performance_(Y) }\end{array}$ & 0.586 & 0.589 & 0.092 & 6.405 & $\begin{array}{r}0.00 \\
0\end{array}$ \\
\hline $\begin{array}{l}\text { Quality of Work life* Work Motivation -> } \\
\text { Organisation Performance_(Y) }\end{array}$ & 0.042 & 0.043 & 0.043 & 0.974 & $\begin{array}{r}0.33 \\
0\end{array}$ \\
\hline
\end{tabular}

Based on the table 3 shows some coefficient as follows:

1. Coefficient is 0.317 shows that the influence of quality of work life to the organisation performance is positive. Based on the coefficient score can be concluded that quality of work life gave significance influences to the PT. Semen Tonasa company performance with significance level is 0.001 .

2. Coefficient is 0.586 shows that the influence of work motivation to the organisation performance is positive. Based on the coefficient score can be concluded that work motivation gave significance influences to the PT. Semen Tonasa company performance with significance level is 0.000 .

3. Work motivation did not moderate the influences of quality of work life to the organisation performance of PT. Semen Tonasa with significance level is 0.330 which describing that the relation is not significant.

\section{Determinant Coefficient}

Determinant coefficient (R2) measures how the competence model describing the bound variables. Determinant coefficient about 0 (zero) to 1 (one), if R2 is getting bigger so, can be said that the exogenous (X) variable influences is big to the endogenous (Y). It means that the model which used is getting bigger to explain the influences of exogenous variable which studied to the endogenous variable. On the other hand, if R2 is getting smaller (near to zero) so, can be said that the influences of exogenous variable to endogenous variable is getting smaller. It means that the model which used is not strong to explain the influences of the free variable (exogenous) which studied to the bound variable (endogenous).

The determinant coefficient score $\left(\mathrm{R}^{2}\right)$ is explain on the table 4 as follows:

Table 4:-R Square Adjusted

\begin{tabular}{|l|l|l|}
\hline & R Square & Adjusted R Square \\
\hline Organisation Performance_(Y) & 0.665 & 0.654 \\
\hline Source: Tabulation Data SmartPLS, 2019. & & \\
\hline
\end{tabular}

The $\mathrm{R}^{2}$ score on the table 4 above explains that organisation performance (y) has determinant coefficient score $\left(\mathrm{R}^{2}\right)$ is 0,654 . It means that the variability of organisation performance that can be explained by the variability of quality of work life and work motivation are 65,4 percen. On the other hand, the contribution influence of quality of work life and work motivation to the PT. Semen Tonasa organisation performance is $65,4 \%$, while the remain is $34.6 \%$ as other variable contribution out of this study.

\section{Discussion: -}

Quality of work life influential toward organisation performance of PT. Semen Tonasa.

Quality of work life positively and significantly influences the organisation performance of PT. Semen Tonasa. This shown that the better quality of work life of the staff will improve the organization performance, quality of work life plays an important role improving the organisation performance. This proved that every indicator of quality of work life is done well. 
This is appropriate with Alfani (2018) concluded that Quality of Work Life influential toward staff performance when the staff has high Quality of Work Life will improve their performance.

Tanaya and Chandan (2015) showed that better QWL is the success to attract and to keep the motivated and have good quality staff which may improve the quality of the company service. Shiney (2012), from his research is found out that QWL has significant relationship with the organisation performance. The variable QWL are the company health and safe policy, free lunch for the staff, transportation for the staff, coaching, leave day, family life, and healthy life.

Quality of work life includes sufficiant and fair, health work environment, safe and secure; the opportunuity to grow and improve; the opportunity to use and to improve skill; the balance between work and personal and family life; good work relationship; and social responsibility of the company to improve the staff proud.

Work motivation influential toward the organization performance of PT. Semen Tonasa.

Work motivation positively and significantly influence the organisation performance of PT. Semen Tonasa. This shown that the better work motivation will influence the improvement of the organisation performance of PT. Semen Tonasa. Staff work motivation play an impotant role in improving the organization performance.

This agree with Matthew Abioro (2013) shown that the staff work motivation has positive influence toward the organisation performance. So, it is recommended that an organisation must seriously pay attention to the staff motivation to facilitate work delivery and the effective performance.

Ovidiu (2013) shows that motivation and performance of the staff are the important means of any organisation long term success, there is positive relationship between staff motivation and the organisation effectiveness. Michael (2016), the empirical proof show that motivated staff will make organisation performance better. Ifrah et al (2017) show significant relationship between motivation means such as salary the staff received and their performance, the research finding shows that $32 \%$ staff motivation toward the organisation performance.

Work motivation is a condition which activates the human and cause spirit or stimulate to do or not to do an activity which is shown in an effort to gain the goal; strong or weak the motivation will influence the prestige gain.

\section{Work motivation does not moderate the influential of quality of work life toward the organisation} performance of PT. Semen Tonasa.

Work motivation does not moderate the influential of quality of work life toward the organisation performance of PT. Semen Tonasa. In this case, work motivation support or strengthen the relationship between quality of work life and the organisation performance of PT. Semen Tonasa. This shown that work motivation will strengthen the relationship of quality of work life toward organisation performance.

Quality of work life is supposed to improve the staff work condition, to improve the organisation effectiveness, so quality of work life plays an important role in implementing the improvement policy in an organisation and to optimalize the organization performance. So that, even if there is no work motivation but the quality of work life is optimalized the organisation performance will be improved as well.

\section{Conclusion and Suggestion: - \\ Conclusion}

1. Quality of work life positively and significantly influenced the organisation performance of PT. Semen Tonasa. This shown that quality of work life plays an important role in improving the organization performance.

2. Work motivation positively and significantly influenced the organisation performance of PT. Semen Tonasa. This shown that staff work motivation plays an important role in improving the organisation performance.

3. Work motivation does not moderate the influence of quality of work life toward organization performance of PT. Semen Tonasa. This shown that the existence of work motivation is to strengthen and to influence the relationship of quality of work life and the organisation performance of PT. Semen Tonasa. This case showed that without work motivation the relationship of quality of work life and the organisation will be strength. 


\section{Suggestion}

1. Motivation variable is the influential Variable in this research, so it is hoped the company to give more attention by improving the staff motivation to improve the organisation performance.

2. It is hoped that the company to always have an effort to improve the staff performance, by giving opportunitis to the staff to involve in making decision with the leaderof the company. And also have the chance to be involved in making company policy.

\section{References:-}

1. Abdillah, W dan Jogiyanto, H, M (2009), Konsep dan Aplikasi PLS (Partial Least Square) Untuk Penelitian Empiris. Yogyakarta Badan Penerbit Fakultas Ekonomi Dan Bisnis UGM.

2. Alfani, Mufti Hasan. 2018. Analisis Pengaruh Quality Of Work Life (QWL) terhadap Kinerja dan Kepuasan Kerja Karyawan PT. Bank BRI Syariah Cabang Pekanbaru. VOL 1 NO 1 (2018): Jurnal Tabarru’: Islamic Banking and Finance

3. Asosiasi Semen Indonesia, 2018. Semen Indonesia catatkan total volume penjualan 30,2 juta ton sampai November 2018. https://industri.kontan.co.id/news/semen-indonesia-catatkan-total-volume-penjualan-302-jutaton-sampai-november-2018

4. Ahmed, L. 2010. A mediation of customer saticfaction relationship between service quality and repurchase intentions for the telecom sector in Pakistan: A Case study of University students, African Journal of Business Management, Vol. 4, no 16, pp, 3457-3462.

5. Aragon-Sanchez, Antonio dan Gregorio Sanchez-Marin. 2005. Strategic Orientation, Management Characteristic, and Performance: A Study of Spanish SMEs. Journal of Business Management 43(3); pp. 287308

6. Cherrington, David J, 1995. The Management of Human Resources (4th. Edition). New Jersey: Prentice Hall Inc.

7. Costello, S.J.1994. Effective Performance Management. New York: Mc GrawHill Companies, Inc.

8. Gibson, Vancevich, Donell, 1998. Organisasi dan Manajemen, Edisi Keempat, Erlangga, Jakarta.

9. Gobel, R. 2010. Meningkatkan Daya Saing Industri Nasional Menghadapi Persaingan Global. [On-line]. Accessed on 15 Merch 2019 at http://inspirasitabloid.wordpress.com/

10. Ifrah Abdullahi Hussein, Fridah Simba. 2017. Effect of Employee Motivation On Organizational Performance of Mogadishu Al Port In Somalia.The Strategic Journal of Business \& Change Management. ISSN 2312-9492 (Online) 2414-8970(Print).www.strategicjournals.com

11. Iyigun, O., dan Tamer, I. 2012. The impact of perceived organizational justice on turnover intention: evidence from an international electronic chain store operating in Turkey. Journal of global strategic management, 11, 14-25.

12. Jauch, Lawrence R. dan William F. Glueck, (1998), "Manajemen Strategis dan Kebijakan Perusahaan”, Edisi ketiga, Erlangga, Jakarta.

13. Lewis, Philip, V. (1987). Organizational Communication Theory and Practice. New York: John Wiley \& Sons Inc.

14. Maslow, Abraham H. 1994. Motivasi dan Kepribadian (Teori Motivasi dengan Pendekatan hierarki Kebutuhan Manusia). PT PBP, Jakarta

15. Matthew Abioro. Effect of employee motivation on organizational performance. , University of Agriculture, Abeokuta. Original Article. Acta de Gerencia Ciencia. Vol-1: No-3: 2013: 17-27. www.cagena.com

16. Mangkunegara, A.P. 2007. Evaluasi Kinerja Sumber Daya Manusia. Bandung: PT. Refika Aditama.

17. Michael, T.Lee ${ }^{a}$ Robyn L.Raschke. 2016. Understanding employee motivation and organizational performance: Arguments for a set-theoretic approach. Journal of Innovation \& Knowledge. Volume 1, Issue 3, SeptemberDecember 2016, Pages 162-169. https://doi.org/10.1016/j.jik.2016.01.004

18. Ovidiu, Dobre. 2013. Employee motivation and organizational. The Bucharest University of Economic Studies. ISSN: 2247-6172; ISSN-L: 2247-6172 Review of Applied Socio- Economic Research (Volume 5, Issue 1/ 2013), pp. 53 URL: http://www.reaser.eu

19. Roos, G., Fernstrom, L. \& Pike, S. 2005. Intellectual Capital Management Approach in ICS Ltd, Journal of Intellectual Capital, 6 (4), pp.489- 509.

20. Robbins dan Judge. (2007). Perilaku Organisasi. Edisi 12, Buku 1 Edisi Bahasa Indonesia. Jakarta: Salemba Empat.

21. Schwartz, Andrew E. (1999). Performance Management. Barrons’ Educational Series, Inc., New York.

22. Spector, P. E. 2000. Industrial and Organizational Psychology: Research and Practice (Second Edition). New York: John Wiley \& Sons, Inc. 
23. Shiney Chib. 2012. Quality of Work Life and Organisational Performance Parameters at Workplace. Datta Meghe Institute of Management Studies, Nagpur, India. SEGi Review ISSN 1985-5672 Vol. 5, No. 2, December 2012, 36-47.

24. Tanaya, Nayak dan Chandan, Kumar Sahoo. Quality of work life and organizational performance: Empirical evidence from Dhaka Export Processing Zone. National Institute of Technology Rourkela. Journal of Health Management 17(3):263-273 · September 2015. DOI: 10.1177/0972063415589236

25. Ulum, Ihyaul. 2009. Intelectual Capital: Konsep dan Kajian Empiris. Yogyakarta: Graha Ilmu

26. Umar, Husen. 2008. Metode Riset Bisnis. Jakarta: PT Gramedia Pustaka Utama

27. Zin, Razali Mat. 2004. Perception of Professional Engineers Toward Quality of Work Life and Organizational Commitment. Gadjahmada International Journal of Business. Vol.6 No.3 323-324. 